\title{
Canada's plans for industrial research hit by economies
}

\begin{abstract}
Ottawa. Funding for a key federal research programme designed to increase Canada's industrial competitiveness has been virtually halved by the country's conservative government as part of its latest round of cuts in public spending. Participating scientists have been advised to seek more money from industry, but many say this is unrealistic.

Robert Nicholson, the minister for science, announced last week that the Networks of Centres of Excellence (NCE) programme will receive $\mathrm{C} \$ 125$ million over the next four years. This contrasts sharply with the C\$240 million with which the programme was launched in 1989.
\end{abstract}

The original money has been used to fund 15 networks of scientists carrying out fundamental and long-term applied research with the potential for transfer to industry. Government officials had earlier indicated that funding reductions were likely, but the decision has still upset many participants.

The NCE programme at present involves more than 800 researchers, 1,300 graduate students and 400 postdoctoral fellows and more than 140 companies. Research areas covered include biotechnology, natural resources, telecommunications and microelectronics, robotics and intelligent systems, space, advanced materials and processes, human genetic diseases, human ageing and medical advances and health care.

\section{Gemini telescopes in suspended animation}

London \& Washington. Last-minute hesitation by Canada's National Research Council (NRC) led to the postponement last week of a ceremony in Washington at which a formal agreement was to have been signed between research agencies in the United States, Britain and Canada to build a pair of ground-based 8-metre telescopes.

Construction work on the telescope project, known as Gemini, has already begun, under the leadership of the US National Science Foundation (NSF). One of the telescopes is to be based at Mauna Kea in Hawaii, and the other on Cerro Pachon in Chile; when completed at the end of the decade, the telescopes, which are optimized to operate in the optical/infrared range, will give complete coverage of both the Northern and Southern Hemispheres with a spatial resolution even superior to that of the Hubble space telescope.

Officials on both sides of the Atlantic have been putting a brave face on the lastminute hitch, insisting that the agreement could still be signed within the next few weeks. Canada had previously promised to provide 15 per cent of the project's cost of $\$ 176$ million, and NRC officials say they hope the delay - the result of an across-theboard review of science spending - will be only temporary. But others warn that, if Canada does change its mind, this could cause the project serious problems. Under an initial agreement reached in 1990, the NSF agreed to cover half of the construction costs, with the other half divided equally between the NRC and Britain's Science and Engineering Research Council (SERC). Progress on formalizing this agreement stalled, however, when a budget crisis at the SERC meant it had to back out of its commitment.

Since then, funding problems in Canada led the NRC to reduce its planned contribution to 15 per cent. Half of the remaining 10 per cent of the costs will now be paid for by the government of Chile, and the other half shared equally by Brazil and Argentina. Meanwhile the position of the SERC, which has given a large optical telescope high priority in its spending plans since 1986, has improved. The council's chairman, Sir Mark Richmond, was able to fly to Washington last week prepared to sign a formal agreement pledging Britain's contribution of $\$ 44$ million, and issued a statement describing Gemini as "well matched to the strengths and future needs of UK astronomy".

It was only after he had arrived that Canada announced it was not yet ready to sign. NRC officials emphasize that their commitment to Gemini is not diminished. "But we have to make absolutely sure that our commitments are sound, and that we don't get into the over-stretched position that the SERC was in", says Dr Clive Willis, the council's vice-president of physical and life sciences. "We thought it would be prudent to wait just for a little while."

In common with other Canadian government departments, the NRC has been promised a budget increase of almost ten per cent next year. But according to a spokesperson for the council, it expects unspecified cuts in subsequent years, when most of Gemini would have to be paid for.

Donald Morton, director of the NRC's Herzberg Institute of Astrophysics, and Canada's representative on Gemini's international board, says that he hopes Canada will sign within a few weeks. Wayne van Citters, director of advanced technologies at the NSF, says he is similarly optimistic.

David Dickson \& Colin Macilwain
Although critics have contended that political considerations have had an excessive influence on funding decisions, and that much time has been wasted by bureaucratic regulations, the programme has in general been considered a success.

But some of the centres receiving government support have expressed doubts about their ability to raise more funds from industry. In some of the research areas involved, no appropriate industrial sponsors exist.

Existing networks will have to compete to renew their funding from the federal government. They have been invited to submit proposals by 29 October, and told that the results will be known early in 1994. Once the initial competition is completed, a second will be held for funding new networks, although this will depend on how much money remains.

In announcing the cut in funding, Nicholson said it should be considered in the context of the government's record of investment in science and technology, and pointed out that this has recently been increasing at a higher rate than other areas of public spending.

The Liberal Party's science spokesman David Berger said he was shocked by the decision. Howard McCurdy of the New Democratic Party said the cuts show "the Tories can't even recognize success when it's right under their nóses".

David Spurgeon

\section{City scientists strike rich}

London. Four scientists who worked in a team developing environmental sensors at City University, London, struck rich last week when the company set up by the university to exploit their results was sold to outside investors for $£ 27$ million (\$40 million).

The deal is thought to be the biggest of its kind negotiated by a British university. Working together in City's Wolfson Unit for Electrochemical Technology, the scientists developed a technique for monitoring the presence of poisonous gases such as carbon monoxide and hydrogen sulphide.

Portable devices based on their work now have worldwide sales of $£ 300,000$ a year. They are produced by City Technology Ltd, a company set up on the university campus in 1976, and now based in Portsmouth. Last year it made a profit for the university of almost $£ 4$ million.

The university is to use its share of the proceeds of the sale to build a new research block and two halls of residence. It will also establish an endowment fund to support new research initiatives. The scientists, who each expect to receive about half a million pounds after tax, say that most of the money will be used to pay off their mortgages and to reinvest in the company. David Dickson 